\title{
ANALISIS POTENSIALITAS EKONOMI DAN KETIMPANGAN WILAYAH DI KABUPATEN SUMEDANG
}

\author{
Potentialities Economics Analysisand Inequality Region \\ In The District Sumedang
}

Endah Djuwendah

Program Studi Agribisnis Fakultas Pertanian, Universitas Padjadjaran
endah_djuwendah @ unpad.ac.id

\begin{abstract}
Economic growth with its process are the main condition for the sustainability of the regional economic development. In addition, high income inequality also shows the heterogeneity between regions, as seen in Bekasi regency with a rapid growth rate. This research purposes were to identify the sector which is a base in the region growth, the economic structure change in each district, and measure the level of regional inequality in Sumedang regency. This research design was descriptive qualitative and methods chosen was survey with an analytical unit of 26 districts in Sumedang regency and its object are regional income (GDP), populations and the GDP is based upon the labor fields of each district during 2008-2012.The analysis tool used is Location Quotient, Classical Shift Share, and Williamson Index.

The research results showed that The region with a growth rate and higher competitiveness of other regions were Jatinangor, Cimalaka, North Sumedang, , Sumedang south, Cimanggung, Paseh, Tanjungsari and Pamulihan. Four sectors have growth that is slower than the average growth of all sectors were agriculture, mining/quarrying, manufacturing and services. Total Change growth and the highest shift to agriculture occurred in the District Buahdua, mining / quarrying in District Paseh, the manufacturing sector in Sumedang District of northern sector of electricity, gas, water and buildings in the District Jatinangor sector trade, hotels and restaurants in the District of Sumedang Utara, transport, communications, finance, leasing, and services companies in the District of South Sumedang and services sectors in the District Jatinangor. Changes in total with the highest positive values contained in five sub-districts Jatinangor, North Sumedang, Cimanggung, South Sumedang and Tanjungsari. There was a transformation of the economic structure of Sumedang from the primary sector to the secondary and tertiary sectors. Potential sectors that become leading sector, made a great contribution because it has advantages kompetitif and comparative, be able to specialize in rural areas was agriculture while urban areas was manufacturing, trade, hotels and restaurant and the services. Inequality of income distribution Sumedang was relatively low $(0,2-0,5)$ and the regional disparity in Sumedang including moderate with relatively stable inequality index value of 0.44 .
\end{abstract}

Keyword : economic potentiality, regional disparity

\section{PENDAHULUAN}

Kabupaten Sumedang meupakan salah satu daerah strategis dalam jalur mobilisasi karena berada di antara dua kota besar Bandung dan Cirebon. Sebagai hinterland dari

$$
\begin{aligned}
& \text { Bandung raya, Kabupaten } r \text { Sumedang } \\
& \text { mengalami pertumbuhan jumlah } \\
& \text { dan penduduk } \\
& \text { baik serta memiliki sumber daya }
\end{aligned}
$$


dalam pembangunan. Kabupaten Sumedang merupakan salah satu penyumbang sektor pertanian bagi perekonomian Jawa Barat dan lokasi berdirinya berbagai perguruan tinggi terkemuka sebagai tempat investasi sumber daya manusia. Selain itu juga terdapat pembangunan sejumlah mega proyek nasional seperti Waduk Jatigede, tol Cisumdawu (Cileunyi-Sumedang-Dawuan) dan Bandara Kertajati di Majalengka yang akan berpengaruh terhadap perekonomian wilayah Sumedang di masa mendatang.

Peran strategis Kabupaten Sumedang dalam pembangunan Jawa Barat tentunya tidak terlepas dari kuatnya pondasi pembangunan di seluruh wilayah Kabupaten Sumedang, yang terdiri dari 26 Kecamatan. Dalam empat tahun terakhir (2010-2014) perekonomian Kabupaten Sumedang mengalami pertumbuhan yang fluktuatif. Laju pertumbuhan yang berfluktuasi terjadi tahun 2012 dengan laju pertumbuhan sebesar 6,56 persen. Hal ini disebabkan tingginya laju pertumbuhan yang ekstrim di kategori konstruksi, sebesar 25,12 persen. Sedangkan tahun 2013-2014 mengalami perlambatan laju pertumbuhan. Dilihat dari pola pertumbuhan masing-masing sektor, terlihat trend pertumbuhan pada kelompok sektor primer cenderung (selalu) lebih rendah dibanding dengan pertumbuhan pada kelompok sektor sekunder dan tersier. Dalam jangka panjang, kondisi ini akan semakin mempercepat proses transformasi dalam struktur ekonomi di Kabupaten Sumedang.
Pada tahun 2014, perekonomian Kabupaten Sumedang mengalami perlambatan dibandingkan pertumbuhan tahun-tahun sebelumnya. Laju pertumbuhan PDRB Sumedang tahun 2014 mencapai 4,70 persen, sedangkan tahun 2013 sebesar 4,84 persen. Perlambatan laju pertumbuhan disebabkan karena pengaruh menurunnya produksi pertanian terutama tanaman bahan makanan terutama tanaman padi. Cuaca dan kekeringan yang panjang sebagai penyebab rendahnya produksi padi. Disamping itu, keadaan ekonomi nasional dan kebijakan pemerintah pusat diantaranya kenaikan harga Bahan Bakar Minyak (BBM), Tarip Dasar Listrik (TDL) dan tingginya suku bunga bank kebijakan pemerintah (BI rate) berdampak pada perlambatan ekonomi Kabupaten Sumedang (BPS, 2015).

Terkait dengan visi dan misi RPJMD 2014-2018 mengenai bidang perekonomian yaitu mengembangkan perekonomian Kabupaten Sumedang yang berdaya saing dan berkeadilan, memberdayakan dan melindungi kelompok usaha kecil dan menengah serta meningkatkan ketersediaan dan kualitas infrastruktur wilayah, maka kajian potensialitas ekonomi wilayah serta gambaran pola perubahan dan pertumbuhan sektoral dalam perekonomian Kabupaten Sumedang sangat diperlukan. 


\section{KAJIAN LITERATUR}

Menurut Adisasmita (2008), pembangunan wilayah (regional development) merupakan fungsi dari potensi sumberdaya alam, tenaga kerja dan sumberdaya manusia, investasi modal, prasarana pembangunan, transportasi dan komunikasi, komposisi industri, teknologi, situasi ekonomi dan perdagangan antar wilayah, kemampuan pendanaan dan pembiayaan pembangunan daerah, kewirausahaan, kelembagaan daerah serta lingkungan pembangunan secara luas. Keberhasilan pembangunan wilayah salah satunya dapat ditunjukkan oleh kemajuan ekonomi daerah tersebut. Sedangkan Sirojuzilam( 2008) menyatakan bahwa pertumbuhan ekonomi merupakan indikator penting bagi daerah untuk mengevaluasi keberhasilan pembangunan serta berbagai sektor ekonomi yang secara tidak langsung menjelaskan tentang tingkat pertumbuhan yang terjadi.

Dalam pembangunan akan terjadi perubahan struktur ekonomi. Menurut Kuznezts dalam suparno (2008), perubahan struktur ekonomi suatu negara atau disebut transformasi struktural merupakan serangkaian perubahan yang saling terkait satu sama lain dalam komposisi penawaran agregat, permintaan agregat, serta perdagangn eksporimport. Perubahan struktural merupakan prasyarat dari peningkatan dan kesinambungan pertumbuhan serta penanggulangan kemiskinan sekaligus pendukung bagi keberlanjutan pembangunan itu sendiri (Todaro, 2006). Perubahan struktural menitikberatkan pada perubahan struktur ekonomi dari pola pertanian ke struktur yang lebih modern serta memiliki sektor jasa dan industti manufaktur yang tangguh.

Pertumbuhan ekonomi yang cepat akan menimbulkan ketimpangan distribusi pendapatan. Hal ini disebabkan adanya perbedaan tingkat pertumbuhan ekonomi dengan pertumbuhan penduduk dan perubahan struktur ekonomi. Ketimpangan wilayah (regional disparity) terjadi karena tidak adanya pemerataan dalam pembangunann ekonomi. Menurut Safrizal (1997), ketimpangan yang terjadi antar wilayah disebabkan oleh perbedaan potensialitas Kandungan sumberdaya alam dan kondisi demografi yang terdapat pada masing-masing wilayah sehingga kemampuan suatu daerah dalam mendorong proses pembangunan menjadi berbeda. Perbedaan kekayaan daerah pada akhirnya menimbulkan adanya daerah maju (develop region) dan wilayah terbelakang (underdevelop region). Ketimpangan pada kenyataanyaa tidak dapat dihilangkan. Ketimpangan akan memberikan dorongan kepada daerah terbelakang untuk berusaha mening-katkan kualitas hidupnya agar tidak tertinggal dengan daerah lainnya. Disisi lain dampak negatif dari ketimpangan adalah inefisiensi ekonomi, melemahkan stabilitas sosial dan solidaritas serta munsulnya ketidakadalan (Todaro, 2006). 


\section{METODE PENELITIAN}

Obyek dalam penelitian ini adalah struktur perekonomian wilayah guna melihat pergeseran peran sektoral dan identifikasi sektor ekonomi potensial di Kabupaten Sumedang dalam kurun waktu 2008-2012. Tempat penelitian dipilih secara sengaja (purposive) dengan pertimbangan Kabupaten Sumedang adalah wilayah yang sedang mengalami pertumbuhan ekonomi yang cukup baik.

Desain penelitian yang digunakan adalah kualitatif deskriptif dan teknik penelitiannya adalah survei. Unit analisisnya adalah 26 kecamatan yang berada di Kabupaten Sumedang. Data yang digunakan adalah data sekunder berupa data PDRB per kecamatan berdasarkan lapangan usaha yang diperoleh dari BPS Kabupaten Sumedang, data PDRB per kapita dan jumlah penduduk per kecamatan. Selain itu data diperoleh melalui studi kepustakaan dari berbagai literature berupa teks, jurnal, laporan penelitian dan sumber lain yang berhubungan dengan permasalahan yang dibahas.

Alat analisis yang digunakan adalah analisis Location Quotient (LQ), analisis efek pengganda sektor basis (base multiflier), analisis Shift Share klasik dan Indeks

\section{HASIL DAN PEMBAHASAN}

\begin{tabular}{|c|c|c|}
\hline Perge & dan & Peranan \\
\hline $\begin{array}{l}\text { Sektoral } \\
\text { Kabupaten }\end{array}$ & $\begin{array}{l}\text { Perekonomian } \\
\text { Sumedang }\end{array}$ & Wilayah \\
\hline
\end{tabular}

Williamson. Location Quotient (LQ) adalah suatu perbandingan tentang besarnya peranan suatu sektor di suatau daerah terhadap besarnya peranan sektor tersebut secara nasional (Tarigan, 2007). LQ berguna untuk membantu menentukan kapasitas ekspor perkonomian daerah dan melihat kemampuan daya saing konoditas antar daerah atau sektor unggulan suatu wilayah ( Dedy Makmun dan Sonny, 2012). Analisis pengganda basis menunjukkan pertumbuhan pendapatan atau tenaga kerja dalam wilayah karena penggandaan jumlah pembelanjaan kembali pendapatan dari barang dan jasa yang diproduksi dalam wilayah dan dipasarkan ke luar wilayah (ekspor). Analisis Shift Share digunakan untuk mengukur pergeseran danperanan perekonomian daerah. Secara ri ngkas analisis Shift Share dapat menjelaskan bahwa perubahan variabel regional suatu sektor di suatu wilayah dalam kurun waktu tertentu dipengaruhi oleh pertumbuhan nasional, bauran industri dan keunggulan kompetitif (Tarigan, 2007). Sedangkan tingkat ketimpangan pendapatan antar wilayah diukur menggunakan analisis Indeks Williamson.

Tingkat pertumbuhan perekonomian masing-masing kecamatan diketahui melalui analisis share yang mengasumsikan bahwa tingkat pertumbuhan per sektor dari masing- 
masing kecamatan sama dengan tingkat pertumbuhan rata-rata di Kabupaten Sumedang . Jika suatu kecamatan tumbuh pada tingkat yang sama dengan tingkat pertumbuhan ekonomi Kabupaten Sumedang berarti kecamatan tersebut mampu mempertahankan peranannya dalam perekonomian wilayah Kabupaten Sumedang. Pada kenyataannya, beberapa sektor tumbuh lebih cepat dari sektor-sektor lainnya dan beberapa wilayah lebih maju daripada wilayah lainnya. Oleh karena itu, perlu identifikasi penyebabnya dan mengukur perbedaan yang timbul dengan memisahkan komponen pertumbuhan nasional dengan komponen pertumbuhan sektoral dan pertumbuhan daya saing wilayah.

Menurut Tambunan (2000), untuk meningkatkan pendapatan per kapita, pertumbuhan ekonomi menjadi salah satu target yang sangat penting yang harus dicapai dalam proses pembangunan. Dengan kata lain pertumbuhan ekonomi dapat mencerminkan kinerja perekonomian suatu daerah. Laju pertumbuhan ekonomi atau sering kita kenal dengan sebutan LPE merupakan salah satu indikator makro ekonomi yang bisa menggambarkan perkembangan atau tingkat kinerja perekonomi suatu wilayah.

Tabel 1. Komponen Pertumbuhan Nasional Kabupaten Sumedang Tahun 2008-2012

\begin{tabular}{|c|c|c|c|c|c|c|c|c|c|c|c|}
\hline No & Kecamatan & PN1 & PN2 & PN3 & PN4 & PN5 & PN6 & PN7 & PN8 & PN9 & PNJ \\
\hline 1 & Jatinangor & 7840.82 & - & 68831.46 & 2605.52 & 2540.06 & 26153.84 & 1398.90 & 4736.90 & 9567.64 & 123675.13 \\
\hline 2 & Cimanggung & 8356.80 & - & 81653.75 & 2595.99 & 2153.75 & 8086.70 & 817.51 & 2234.32 & 2688.43 & 108587.26 \\
\hline 3 & Tanjungsari & 15087.30 & 24.17 & 11920.73 & 2094.23 & 2400.96 & 15695.87 & 3116.83 & 3345.59 & 4677.46 & 58363.13 \\
\hline 4 & Rancakalong & 11421.89 & - & 5124.49 & 1158.13 & 1436.03 & 5590.25 & 862.41 & 1354.64 & 2412.75 & 29360.60 \\
\hline \multirow[t]{2}{*}{5} & Sumedang & & & & & & & & & & \\
\hline & Selatan & 14115.63 & - & 6995.78 & 1502.23 & 2283.62 & 31818.84 & 7373.62 & 4848.06 & 9809.07 & 78746.84 \\
\hline 6 & Sumedang Utara & 12298.36 & - & 13073.53 & 1657.75 & 2158.10 & 68079.69 & 4415.87 & 5056.83 & 7570.35 & 114310.49 \\
\hline 7 & Situraja & 17088.71 & - & 5017.65 & 1102.96 & 641.91 & 11030.12 & 1462.77 & 1926.01 & 3307.52 & 41577.65 \\
\hline 8 & Darmaraja & 14737.10 & 11.56 & 4606.33 & 732.37 & 902.99 & 9025.38 & 1377.38 & 1657.04 & 3167.64 & 36217.78 \\
\hline 9 & Wado & 16399.21 & - & 4937.62 & 1262.25 & 1170.97 & 10010.44 & 1676.94 & 1606.97 & 2662.92 & 39727.31 \\
\hline 10 & Jatigede & 8445.60 & - & 2473.19 & 613.28 & 670.48 & 2596.55 & 656.22 & 775.07 & 1432.63 & 17663.01 \\
\hline 11 & Tomo & 9404.17 & 227.82 & 5954.45 & 593.15 & 635.29 & 6864.20 & 680.10 & 1152.74 & 2029.90 & 27541.82 \\
\hline 12 & Ujungjaya & 17348.07 & 147.61 & 4269.03 & 803.64 & 778.67 & 5567.72 & 845.18 & 965.50 & 2092.95 & 32818.35 \\
\hline 13 & Conggeang & 14500.89 & 55.56 & 6770.77 & 918.61 & 819.08 & 7299.15 & 1338.73 & 1367.95 & 2103.79 & 35174.54 \\
\hline 14 & Paseh & 8680.42 & 229.65 & 8061.04 & 806.47 & 841.89 & 8572.21 & 1319.42 & 905.64 & 2140.72 & 31557.48 \\
\hline 15 & Cimalaka & 13988.90 & 422.73 & 10878.15 & 1383.01 & 1365.83 & 15529.79 & 3051.33 & 2187.17 & 4672.08 & 53478.98 \\
\hline 16 & Tanjungkerta & 12096.25 & - & 4295.61 & 1089.79 & 842.38 & 7370.35 & 1446.25 & 1711.25 & 3294.82 & 32146.71 \\
\hline 17 & Buahdua & 25401.16 & 93.20 & 2952.57 & 986.28 & 757.14 & 7270.75 & 1140.82 & 1506.63 & 2924.21 & 43032.76 \\
\hline 18 & Cibugel & 8835.56 & - & 1475.96 & 420.33 & 388.18 & 2633.14 & 557.67 & 476.47 & 1207.81 & 15995.10 \\
\hline 19 & Tanjungmedar & 4398.60 & - & 420.47 & 276.36 & 218.69 & 2324.34 & 258.24 & 389.04 & 1075.21 & 9360.95 \\
\hline 20 & Cisitu & 5919.99 & - & 1051.76 & 615.48 & 278.17 & 3409.39 & 373.70 & 720.63 & 1880.22 & 14249.35 \\
\hline 21 & Pamulihan & 6265.92 & 1.45 & 4864.67 & 615.98 & 560.59 & 5378.48 & 437.87 & 369.63 & 1384.64 & 19879.23 \\
\hline 22 & Ganeas & 3428.01 & - & 1322.55 & 477.76 & 315.31 & 2239.49 & 699.13 & 685.61 & 1375.63 & 10543.49 \\
\hline 23 & Jatinunggal & 6627.20 & - & 855.81 & 514.55 & 599.56 & 3143.07 & 277.95 & 596.64 & 1828.19 & 14442.95 \\
\hline 24 & Sukasari & 3815.56 & - & 1700.70 & 460.33 & 388.02 & 2623.57 & 567.43 & 780.70 & 1027.83 & 11364.13 \\
\hline 25 & Cisarua & 2928.79 & - & 1480.50 & 485.73 & 322.06 & 3411.11 & 447.91 & 615.91 & 1212.03 & 10904.05 \\
\hline 26 & Surian & 3214.19 & 4.19 & 253.75 & 313.71 & 263.03 & 503.61 & 241.86 & 162.94 & 737.18 & 5694.45 \\
\hline
\end{tabular}

Keterangan:

Pni.j = Komponen pertumbuhan nasional dari sektor ke-i untuk kecamatan ke-j

$\mathrm{PN} . \mathrm{J}=\quad$ Komponen pertumbuhan nasional dari seluruh sektor untuk kecamatan ke-j 
Berdasarkan Tabel 2, diketahui terdapat empat sektor yang memiliki angka pertumbuhan negatif di semua kecamatan yaitu: sektor pertanian, sektor pertambangan/penggalian, industri pengolahan dan Jasa. Hal ini menunjukkan bahwa keempat sektor tersebut memiliki pertumbuhan yang lebih lambat dibandingkan dengan pertumbuhan rata-rata seluruh sektor di Kabupaten Sumedang. Sedangkan 5 sektor lainnya yaitu sektor listrik, gas, dan air bersih, sektor bangunan, sektor perdagangan, hotel dan restoran, sektor pengangkutan dan komunikasi, dan sektor keuangan, persewaan dan jasa memiliki angka pertumbuhan sektoral yang positif. Hal ini menunjukkan bahwa pertumbuhan sektor-sektor tersebut lebih cepat dibandingkan dengan pertumbuhan rata-rata seluruh sektor di Kabupaten Sumedang.

Analisis komponen pertumbuhan daya saing wilayah (competitive advantage) digunakan untuk melihat apakah suatu sektor di kecamatan mengalami peningkatan atau penurunan dibandingkan sektor yang sama di kabupaten. Apabila angkanya positif berarti wilayah kecamatan ke-j mempunyai daya saing yang baik dibandingkan dengan wilayah lainnya untuk sektor ke-i karena mampu meningkatkan kompetisinya. Kemampuan daya saing ini dipengaruhi oleh kebijakan ekonomi regional, dukungan kelembagaan, dan akses pasar (Budiharsono, 2001).

Tabel 3. Komponen Pertumbuhan Daya Saing Wilayah di Kab. Sumedang 2008-2012

\begin{tabular}{|c|c|c|c|c|c|c|c|c|c|c|c|}
\hline No & Kecamatan & DS1 & DS2 & DS3 & DS4 & DS5 & DS6 & DS7 & DS8 & DS9 & $\overline{\mathrm{DSJ}}$ \\
\hline 1 & Jatinangor & -2289.55 & - & 5910.945 & 1812.267 & 797.7421 & 6663.644 & 425.9138 & 1445.473 & 3126.168 & 17892.60 \\
\hline 2 & Cimanggung & -276.47 & - & 4587.74 & 1541.61 & 71.67 & 342.57 & -72.95 & -105.55 & -155.59 & 5933.02 \\
\hline 3 & Tanjungsari & 2259.41 & 5.68 & -490.01 & 234.27 & 326.98 & 2396.86 & 897.46 & 412.30 & -188.99 & 5853.94 \\
\hline 4 & Rancakalong & -133.63 & - & 49.25 & -317.08 & -215.47 & 353.51 & -92.59 & -549.55 & -209.14 & -1114.70 \\
\hline 5 & Sumedang & & & & & & & & & & \\
\hline 6 & $\begin{array}{l}\text { Selatan } \\
\text { Sumeda }\end{array}$ & -2437.79 & - & -300.40 & 352.63 & 373.73 & -51.43 & 3916.38 & 2516.44 & 408.92 & 4778.46 \\
\hline & Utara & -194.81 & - & 54.69 & 481.39 & 491.35 & 3398.61 & -185.65 & 1898.75 & 590.26 & 6534.58 \\
\hline 7 & Situraja & 230.60 & - & -655.56 & -504.05 & -168.43 & -2314.90 & -223.24 & -500.44 & -540.81 & -4676.83 \\
\hline 8 & Darmaraja & -36.27 & 3.79 & -440.47 & -238.54 & -78.33 & -2009.00 & -366.28 & -790.81 & -76.67 & -4032.58 \\
\hline 9 & Wado & 831.86 & - & -1025.52 & -129.95 & -86.79 & -1207.49 & -274.09 & -766.63 & -26.68 & -2685.29 \\
\hline 10 & Jatigede & -1079.10 & - & -523.05 & -18.19 & -11.17 & -657.48 & -129.84 & -340.72 & -211.68 & -2971.23 \\
\hline 11 & Tomo & -1191.38 & -21.36 & -1247.21 & -197.00 & -86.24 & -189.78 & -256.05 & -119.02 & -104.56 & -3412.61 \\
\hline 12 & Ujungi: & 149.67 & -22.98 & -794.27 & -234.63 & -160.00 & -630.69 & -333.90 & -177.46 & -196.78 & -2401.03 \\
\hline 13 & Congge & 770.06 & 13.74 & -205.07 & -312.45 & -147.86 & -766.99 & -326.70 & -449.05 & -65.19 & -1489.52 \\
\hline 14 & Paseh & 2945.62 & 83.53 & 1570.75 & 117.03 & 426.47 & 1543.05 & 37.14 & 3.16 & 496.15 & 7222.90 \\
\hline 15 & $\mathrm{Cim}$ & 116.57 & -19.06 & -458.74 & -28.72 & 129.67 & 1423.20 & -1051.21 & -486.53 & -97.07 & -471.90 \\
\hline 16 & Tan & -688.00 & - & -971.20 & -644.48 & -249.18 & -100.23 & -469.36 & -771.82 & -517.39 & -4411.66 \\
\hline 17 & Bual & 1879.46 & 22.23 & -261.53 & -303.86 & -115.29 & -132.58 & -337.78 & -684.53 & -155.77 & -89.64 \\
\hline 18 & Cibug & -156.57 & - & -567.10 & -148.63 & -185.01 & -758.19 & -88.02 & -211.39 & -297.69 & -2412.60 \\
\hline 19 & edar & 318.60 & - & -118.85 & -151.97 & -80.32 & -688.89 & -94.06 & -24.42 & -151.06 & -990.98 \\
\hline 20 & Cisitu & 283.85 & - & -265.53 & -204.91 & -73.75 & -578.24 & -89.13 & -21.44 & -295.22 & -1244.37 \\
\hline 21 & Pamulihan & 889.35 & 0.41 & -578.74 & -34.17 & -35.21 & -65 & 10.60 & 69.38 & -190.61 & -522.73 \\
\hline 22 & Ganeas & -153.50 & - & -389.79 & -177.80 & -115.02 & -371.00 & 7.92 & -116.11 & -41.55 & -1356.86 \\
\hline 23 & Jatinı & 255.33 & - & -221.27 & -112.57 & -67.07 & -636.89 & -98.57 & 41.60 & -203.48 & -1042.93 \\
\hline 24 & Sukas & -303.57 & - & -161.53 & -187.30 & -92.61 & -717.06 & -135.10 & -208.11 & -133.16 & -1938.43 \\
\hline 25 & Cisar & 34.93 & - & -402.84 & -250.30 & -64.29 & -962.41 & -162.69 & 151.93 & -174.05 & -1829.73 \\
\hline 26 & Surian & -114.19 & 0.52 & -86.62 & -184.29 & -109.96 & -198.19 & -103.55 & 33.60 & -121.93 & -884.61 \\
\hline
\end{tabular}


DS.J $=\quad$ Komponen pertumbuhan daya saing wilayah dari seluruh sektor untuk kecamatan ke-j

Berdasarkan Tabel 3, diketahui bahwa Kecamatan Jatinangor, Cimanggung, Tanjung-sari, Sumedang Utara, Sumedang Selatan dan Paseh memiliki daya saing dibandingkan dengan daerah lainnya. Kecamatan Jatinangor memiliki daya saing hampir di semua sektor kecuali pertanian. Kecamatan Cimanggung berdaya saing untuk sektor industri pengolahan, listrik, gas, air bersih, bangunan, perdagangan, hotel dan restoran. Kecamatan Tanjungsari berdaya saing untuk hampir semua sektor kecuali industri pengolahan dan jasa.

Secara keseluruhan (Total Change) antara pertumbuhan dan pergeseran ini, maka untuk sektor pertanian tertinggi perubahannya adalah Kecamatan Buahdua. Sektor Pertambangan/penggalian perubahan tertinggi terjadi di Kecamatan Paseh. Sektor industri pengolahan perubahan yang tertinggi adalah Kecamatan Sumedang utara. Sektor listrik, gas, air bersih dan bangunan yang tertinggi pertumbuhan dan pergeserannya adalah Kecamatan Jatinangor. Sektor perdagangan, hotel, dan restoran yang tertinggi berada di Kecamatan Sumedang Utara. Pada sektor pengangkutan, komunikasi, keuangan, persewaan, dan jasa perusahaan yang tertinggi pergeserannya adalah Kecamatan Sumedang Selatan. Sektor jasa-jasa yang tertinggi adalah Kecamatan Jatinangor. Perubahan total dengan nilai positif tertingi terdapat pada lima kecamatan yaitu Kecamatan Jatinangor, Sumedang Utara, Cimanggung, Sumedang Selatan dan Tanjungsari.

Tabel 4.Komponen Tingkat Perubahan Total di Kabupaten Sumedang Tahun 2008-2012

\begin{tabular}{|c|c|c|c|c|c|c|c|c|c|c|c|}
\hline $\mathrm{No}$ & Kecamatan & PT1 & PT2 & PT3 & PT4 & PT5 & PT6 & PT7 & PT8 & PT9 & PTJ \\
\hline 1 & Jatinangor & 906.38 & & 72062.85 & 5089.51 & 6002.86 & 43750.8 & 2498.5 & 8077.7 & 1525.03 & 149913.63 \\
\hline 2 & Cimanggung & 3129.77 & - & 83062.78 & 4806.87 & 4485.17 & 11809.83 & 1138.25 & 3022.77 & 2204.42 & 113659.86 \\
\hline 3 & Tanjungsari & 8409.01 & 11.51 & 10966.65 & 2868.40 & 5247.06 & 24654.20 & 5515.29 & 5096.53 & 3917.07 & 66685.72 \\
\hline 4 & Rancakalong & 4521.95 & - & 4974.25 & 1139.63 & 2727.27 & 8280.70 & 1185.14 & 1347.11 & 1908.87 & 26084.92 \\
\hline 5 & Smd.Selatan & 3315.76 & - & 6423.04 & 2242.15 & 5053.35 & 45068.90 & 14841.0 & 9304.30 & 9019.71 & 95268.21 \\
\hline 6 & Smd. Utara & 4818.02 & - & 12619.28 & 2566.52 & 4913.76 & 99938.24 & 6356.82 & 8978.92 & 7235.82 & 147427.38 \\
\hline 7 & Situraja & 7195.98 & - & 4166.76 & 883.26 & 1146.98 & 13326.23 & 1943.98 & 2196.21 & 2362.66 & 33222.06 \\
\hline 8 & Darmaraja & 5970.59 & 6.58 & 3986.54 & 682.64 & 1772.09 & 10789.34 & 1674.42 & 1529.25 & 2704.01 & 29115.46 \\
\hline 9 & Wado & 7516.20 & - & 3719.88 & 1457.72 & 2312.78 & 12987.70 & 2210.43 & 1483.31 & 2310.94 & 33998.96 \\
\hline 10 & Jatigede & 2363.34 & - & 1853.86 & 753.20 & 1362.78 & 3024.52 & 842.41 & 744.47 & 1045.94 & 11990.52 \\
\hline 11 & Tomo & 2641.77 & 33.59 & 4475.44 & 549.06 & 1215.60 & 9543.92 & 751.57 & 1494.96 & 1677.36 & 22383.27 \\
\hline 12 & Ujungjaya & 7220.77 & 12.62 & 3308.57 & 776.20 & 1435.66 & 7264.55 & 918.30 & 1174.35 & 1640.49 & 23751.51 \\
\hline 13 & Conggeang & 6680.64 & 27.14 & 6302.12 & 842.99 & 1530.61 & 9583.49 & 1656.74 & 1466.24 & 1781.60 & 29871.57 \\
\hline 14 & Paseh & 6483.77 & 138.92 & 9317.98 & 1131.42 & 2151.68 & 13698.78 & 1991.97 & 1271.17 & 2375.36 & 38561.05 \\
\hline 15 & Cimalaka & 5818.46 & 82.89 & 9995.93 & 1710.84 & 2928.55 & 23445.04 & 3469.58 & 2575.77 & 4004.27 & 54031.33 \\
\hline 16 & Tanjungkerta & 4242.45 & - & 3157.19 & 726.26 & 1477.04 & 10351.22 & 1673.38 & 1624.14 & 2374.93 & 25626.61 \\
\hline 17 & Buahdua & 12233.01 & 44.71 & 2576.10 & 936.70 & 1436.25 & 10177.62 & 1352.44 & 1424.93 & 2411.22 & 32592.98 \\
\hline 18 & Cibugel & 3444.82 & - & 851.40 & 380.06 & 610.45 & 2975.70 & 738.21 & 455.72 & 762.57 & 10218.93 \\
\hline 19 & Tanjungmedar & 2111.47 & - & 285.25 & 195.64 & 367.81 & 2607.12 & 288.54 & 520.29 & 792.80 & 7168.92 \\
\hline 20 & Cisitu & 2696.85 & - & 745.29 & 569.25 & 496.27 & 4256.40 & 464.54 & 987.53 & 1355.31 & 11571.44 \\
\hline 21 & Pamulihan & 3443.35 & 0.76 & 4096.55 & 740.62 & 1113.56 & 6973.14 & 659.34 & 586.91 & 1024.88 & 18639.11 \\
\hline 22 & Ganeas & 1243.76 & - & 881.27 & 423.13 & 531.11 & 2804.68 & 1043.74 & 843.82 & 1166.04 & 8937.55 \\
\hline 23 & Jatinunggal & 2956.59 & - & 601.22 & 534.63 & 1161.55 & 3820.10 & 313.23 & 876.96 & 1401.37 & 11665.65 \\
\hline 24 & Sukasari & 1251.66 & - & 1472.96 & 391.71 & 702.52 & 3003.27 & 705.59 & 884.97 & 769.11 & 9181.79 \\
\hline 25 & Cisarua & 1228.71 & - & 1020.03 & 360.66 & 595.68 & 3874.67 & 500.92 & 1014.28 & 889.92 & 9484.87 \\
\hline 26 & Surian & 1195.92 & 1.53 & 157.25 & 210.30 & 429.04 & 515.94 & 254.78 & 261.74 & 525.20 & 3551.70 \\
\hline
\end{tabular}


Keterangan:

Pti.j $=\quad$ Komponen tingkat perubahan total dari sektor ke-i untuk kecamatan ke-j

PT.J $=\quad$ Komponen tingkat perubahan total dari seluruh sektor untuk kecamatan ke-j

Pti.j diperoleh dari penjumlahan Pni.j, Psi.j, dan Dsi.j

\section{Kontribusi Sektor dan Pergeseran Struktur Perekonomian}

Tabel 5. Kontribusi Sektoral Berdasarkan Analisis Shiftshare di Kabupaten Sumedang

\begin{tabular}{|c|c|c|c|c|c|c|}
\hline \multirow[b]{2}{*}{ No } & \multicolumn{5}{|c|}{ Kontribusi Sektor (\%) } & \multirow[b]{2}{*}{ Pergeseran Sektor } \\
\hline & Kecamatan & Primer & Sekunder & Tersier & Kontribusi Terbesar & \\
\hline 1 & Jatinangor & 0.60 & 55,46 & 43,93 & Industri Pengolahan & $\mathrm{Ya}$ \\
\hline 2 & Cimanggung & 2.75 & 81,26 & 15,99 & Industri Pengolahan & $\mathrm{Ya}$ \\
\hline 3 & Tanjungsari & 12.63 & 33,90 & 58,75 & Perdagangan hotel \& restoran & Ya \\
\hline 4 & Rancakalong & 17.34 & 33,90 & 48,77 & Perdagangan hotel \& restoran & $\mathrm{Ya}$ \\
\hline 5 & Sumedang Selatan & 3.48 & 14,39 & 82,05 & Perdagangan hotel \& restoran & $\mathrm{Ya}$ \\
\hline 6 & Sumedang Utara & 3.27 & 13,63 & 83,10 & Perdagangan hotel \& restoran & Ya \\
\hline 7 & Situraja & 21.66 & 18,65 & 59,68 & Perdagangan hotel \& restoran & Ya \\
\hline 8 & Darmaraja & 20.53 & 22,12 & 57,35 & Perdagangan hotel \& restoran & $\mathrm{Ya}$ \\
\hline 9 & Wado & 22.11 & 22,03 & 55,86 & Perdagangan hotel \& restoran & $\mathrm{Ya}$ \\
\hline 10 & Jatigede & 19.71 & 33,11 & 47,18 & Perdagangan hotel \& restoran & $\mathrm{Ya}$ \\
\hline 11 & Tomo & 11.95 & 27,87 & 60,17 & Perdagangan hotel \& restoran & $\mathrm{Ya}$ \\
\hline 12 & Ujungjaya & 30,45 & 23,24 & 46,11 & Perdagangan hotel \& restoran & Ya \\
\hline 13 & Conggeang & 22.45 & 29,0 & 48,50 & Perdagangan hotel \& restoran & Ya \\
\hline 14 & Paseh & 17,17 & 32,67 & 50,15 & Perdagangan hotel \& restoran & Ya \\
\hline 15 & Cimalaka & 10,92 & 27,09 & 61,99 & Perdagangan hotel \& restoran & Ya \\
\hline 16 & Tanjungkerta & 16.55 & 20,91 & 62,53 & Perdagangan hotel \& restoran & Ya \\
\hline 17 & Buahdua & 37.67 & 15,18 & 47,15 & Pertanian & Tidak \\
\hline 18 & Cibugel & 33.71 & 18.02 & 48,26 & Pertanian & Tidak \\
\hline 19 & Tanjungmedar & 29.45 & 11,84 & 58,71 & Perdagangan hotel \& restoran & $\mathrm{Ya}$ \\
\hline 20 & Cisitu & 23,31 & 15,65 & 61,03 & Perdagangan hotel \& restoran & Ya \\
\hline 21 & Pamulihan & 18,47 & 31,92 & 49,60 & Perdagangan hotel \& restoran & Ya \\
\hline 22 & Ganeas & 13,92 & 20,53 & 65,47 & Perdagangan hotel \& restoran & Ya \\
\hline 23 & Jatinnunggal & 25,234 & 29,69 & 54,97 & Perdagangan hotel \& restoran & Ya \\
\hline 24 & Sukasari & 13,63 & 27,96 & 58,41 & Perdagangan hotel \& restoran & Ya \\
\hline 25 & Cisarua & 12,95 & 20,83 & 66,20 & Perdagangan hotel \& restoran & $\mathrm{Ya}$ \\
\hline 26 & Surian & 33.71 & 22,43 & 43,86 & Pertanian & Tidak \\
\hline
\end{tabular}

Proses perubahan struktur ekonomi yang terjadi di Kabupaten Sumedang terlihat dari nilai kontribusi sektor primer, sekunder, dan tersier. Menurut data pada Tabel 5, terjadi pergeseran struktur perekonomian hamper di semua kecamatan kecuali di Kecamatan
Buahdua, Cibugel dan Surian. Dengan demikian perekonomian Kabupaten Sumedang mengalami transformasi struktural. Sektor sekunder dan tersier menjadi motor penggerak yang mendorong pertumbuhan ekonomi di Kabupaten Sumedang.

\section{Analisis Sektor Basis ( Keunggulan Komperatif) Wilayah di Kabupaten Sumedang}

Location Quotient (LQ) adalah suatu indeks yang membandingkan tentang peranan suatu sektor di suatu daerah terhadap besarnya peranan sektor tersebut secara nasional (Tarigan, 2007). Dalam penelitian ini, LQ digunakan sebagai dasar dalam melihat struktur perekonomian wilayah Kabupaten Sumedang dengan menentukan sektor-sektor dalam kategori ekspor (basis) atau kelompok lokal (non basis). Asumsinya adalah bila suatu daerah lebih berspesialisasi dalam memproduksi barang, maka akan mengekspor 
barang tersebut sesuai dengan tingkat spesialisasinya.

Tabel 5. Analisis Location Quotient (LQ) Kabupaten Sumedang Tahun 2008

\begin{tabular}{|c|c|c|c|c|c|c|c|c|c|c|c|}
\hline No & Kecamatan & 1 & 2 & 3 & 4 & 5 & 6 & 7 & 8 & 9 & B \\
\hline 1 & Jatinangor & 0.24 & - & 2.17 & 0.82 & 0.81 & 0.79 & 0.31 & 0.92 & 1.00 & 0.52 \\
\hline 2 & Cimanggung & 0.29 & - & 2.93 & 0.93 & 0.78 & 0.28 & 0.21 & 0.50 & 0.32 & 0.65 \\
\hline 3 & Tanjungsari & 0.96 & 0.34 & 0.79 & 1.40 & 1.62 & 1.00 & 1.47 & 1.38 & 1.04 & 0.58 \\
\hline 4 & Rancakalong & 1.45 & - & 0.68 & 1.54 & 1.93 & 0.71 & 0.81 & 1.11 & 1.07 & 0.77 \\
\hline 5 & Sumedang Selatan & 0.67 & - & 0.35 & 0.74 & 1.14 & 1.51 & 2.58 & 1.49 & 1.62 & 0.50 \\
\hline 6 & Sumedang Utara & 0.40 & - & 0.44 & 0.57 & 0.74 & 2.22 & 1.07 & 1.07 & 0.86 & 0.49 \\
\hline 7 & Situraja & 1.53 & - & 0.47 & 1.03 & 0.61 & 0.99 & 0.97 & 1.12 & 1.03 & 0.72 \\
\hline 8 & Darmaraja & 1.52 & 0.26 & 0.49 & 0.79 & 0.98 & 0.93 & 1.05 & 1.10 & 1.14 & 0.74 \\
\hline 9 & Wado & 1.54 & - & 0.48 & 1.24 & 1.16 & 0.94 & 1.16 & 0.98 & 0.87 & 0.70 \\
\hline 10 & Jatigede & 1.78 & - & 0.54 & 1.35 & 1.50 & 0.55 & 1.02 & 1.06 & 1.05 & 0.86 \\
\hline 11 & Tomo & 1.27 & 6.84 & 0.84 & 0.84 & 0.91 & 0.93 & 0.68 & 1.01 & 0.96 & 0.79 \\
\hline 12 & Ujungjaya & 1.97 & 3.72 & 0.51 & 0.95 & 0.94 & 0.63 & 0.71 & 0.71 & 0.83 & 0.76 \\
\hline 13 & Conggeang & 1.54 & 1.31 & 0.75 & 1.02 & 0.92 & 0.77 & 1.05 & 0.94 & 0.78 & 0.74 \\
\hline 14 & Paseh & 1.03 & 6.02 & 0.99 & 1.00 & 1.05 & 1.01 & 1.15 & 0.69 & 0.88 & 0.76 \\
\hline 15 & Cimalaka & 0.98 & 6.54 & 0.79 & 1.01 & 1.01 & 1.08 & 1.57 & 0.99 & 1.13 & 0.64 \\
\hline 16 & Tanjungkerta & 1.40 & - & 0.52 & 1.32 & 1.03 & 0.86 & 1.24 & 1.28 & 1.33 & 0.75 \\
\hline 17 & Buahdua & 2.20 & 1.79 & 0.27 & 0.89 & 0.69 & 0.63 & 0.73 & 0.84 & 0.88 & 0.73 \\
\hline 18 & Cibugel & 2.06 & - & 0.36 & 1.02 & 0.96 & 0.61 & 0.96 & 0.72 & 0.98 & 0.87 \\
\hline 19 & Tanjungmedar & 1.75 & - & 0.17 & 1.15 & 0.92 & 0.93 & 0.76 & 1.00 & 1.49 & 0.93 \\
\hline 20 & Cisitu & 1.55 & - & 0.29 & 1.68 & 0.77 & 0.89 & 0.72 & 1.22 & 1.71 & 0.89 \\
\hline 21 & Pamulihan & 1.18 & 0.06 & 0.95 & 1.21 & 1.11 & 1.01 & 0.61 & 0.45 & 0.90 & 0.84 \\
\hline 22 & Ganeas & 1.21 & - & 0.49 & 1.77 & 1.18 & 0.79 & 1.83 & 1.57 & 1.69 & 0.92 \\
\hline 23 & Jatinunggal & 1.71 & - & 0.23 & 1.39 & 1.64 & 0.81 & 0.53 & 1.00 & 1.64 & 0.89 \\
\hline 24 & Sukasari & 1.25 & - & 0.58 & 1.58 & 1.35 & 0.86 & 1.38 & 1.66 & 1.17 & 0.91 \\
\hline 25 & Cisarua & 1.00 & - & 0.53 & 1.74 & 1.17 & 1.17 & 1.13 & 1.36 & 1.44 & 0.91 \\
\hline \multirow[t]{2}{*}{26} & Surian & 2.10 & 0.61 & 0.17 & 2.15 & 1.82 & 0.33 & 1.17 & 0.69 & 1.68 & 0.95 \\
\hline & $\alpha$ & 0.27 & 0.74 & 0.35 & 0.12 & 0.12 & 0.18 & 0.22 & 0.11 & 0.12 & \\
\hline
\end{tabular}

\section{Keterangan:}

$1=$ sektor pertanian

$2=$ sektor Pertambangan/penggalian

$6=$ sektor perdagangan, hotel dan restoran

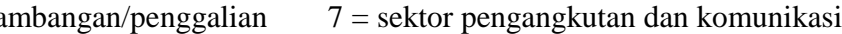

$3=$ sektor industri pengolahan

$4=$ sektor listrik,gas dan air bersih

$8=$ sektor keuangan, persewaan dan jasa

Perusahaan

$5=$ sektor bangunan/konstruksi

$9=$ sektor jasa-jasa

$\alpha=$ koefisien lokalisasi

$\beta=$ koefisien spesialisasi

Simbol $\alpha$ menunjukkan nilai koefisien lokalisasi yaitu suatu analisis yang digunakan untuk mengukur tingkat konsentrasi atau pemusatan suatu kegiatan tertentu di suatu wilayah. Simbol $\beta$, menunjukkan nilai koefisien spesialisasi yaitu suatu analisis yang digunakan untuk mengukur tingkat spesialisasi suatu wilayah dalam kegiatan tertentu. Berdasarkan Tabel 5 dan 6, diperoleh nilai $\alpha$ dan $\beta$ kurang dari satu, artinya tidak terjadi pemusatan aktifitas sektor di wilayah tertentu dan tidak terjadi spesialisasi kegiatan suatu sektor di seluruh kecamatan yang ada di Kabupaten Sumedang.

Tabel 6. Analisis Location Quotient (LQ) Kabupaten Sumedang Tahun 2012

\begin{tabular}{clrrrrrrrrrr}
\hline No & Kecamatan & 1 & 2 & 3 & 4 & 5 & 6 & 7 & 8 & 9 & B \\
\hline 1 & Jatinangor & 0.22 & - & 2.12 & 0.88 & 0.82 & 0.79 & 0.32 & 0.94 & 1.02 & 0.52 \\
2 & Cimanggung & 0.28 & - & 2.93 & 1.01 & 0.78 & 0.28 & 0.20 & 0.49 & 0.32 & 0.64 \\
3 & Tanjungsari & 0.97 & 0.35 & 0.77 & 1.39 & 1.62 & 1.00 & 1.50 & 1.38 & 1.01 & 0.56 \\
4 & Rancakalong & 1.47 & - & 0.69 & 1.50 & 1.92 & 0.73 & 0.81 & 1.06 & 1.07 & 0.77 \\
5 & Sumedang Selatan & 0.63 & - & 0.33 & 0.75 & 1.13 & 1.46 & 2.70 & 1.55 & 1.57 & 0.48 \\
6 & Sumedang Utara & 0.38 & - & 0.42 & 0.56 & 0.73 & 2.14 & 1.01 & 1.08 & 0.83 & 0.49 \\
7 & Situraja & 1.59 & - & 0.48 & 0.99 & 0.61 & 0.99 & 0.98 & 1.11 & 1.04 & 0.72 \\
\hline
\end{tabular}




\begin{tabular}{|c|c|c|c|c|c|c|c|c|c|c|c|}
\hline 8 & Darmaraja & 1.57 & 0.29 & 0.50 & 0.77 & 1.00 & 0.93 & 1.04 & 1.06 & 1.17 & 0.74 \\
\hline 9 & Wado & 1.59 & - & 0.48 & 1.25 & 1.18 & 0.95 & 1.16 & 0.93 & 0.89 & 0.70 \\
\hline 10 & Jatigede & 1.84 & - & 0.56 & 1.42 & 1.58 & 0.56 & 1.05 & 1.04 & 1.08 & 0.87 \\
\hline 11 & Tomo & 1.28 & 6.94 & 0.84 & 0.82 & 0.92 & 0.96 & 0.66 & 1.03 & 0.98 & 0.79 \\
\hline 12 & Ujungjaya & 2.07 & 3.78 & 0.51 & 0.95 & 0.95 & 0.65 & 0.70 & 0.72 & 0.85 & 0.76 \\
\hline 13 & Conggeang & 1.59 & 1.40 & 0.76 & 0.99 & 0.92 & 0.78 & 1.04 & 0.91 & 0.79 & 0.74 \\
\hline 14 & Paseh & 1.05 & 6.21 & 0.99 & 0.98 & 1.09 & 1.01 & 1.12 & 0.67 & 0.88 & 0.74 \\
\hline 15 & Cimalaka & 0.98 & 6.47 & 0.78 & 1.00 & 1.02 & 1.10 & 1.49 & 0.95 & 1.13 & 0.63 \\
\hline 16 & Tanjungkerta & 1.44 & - & 0.52 & 1.24 & 1.03 & 0.88 & 1.22 & 1.24 & 1.34 & 0.76 \\
\hline 17 & Buahdua & 2.32 & 1.95 & 0.27 & 0.89 & 0.71 & 0.66 & 0.73 & 0.82 & 0.91 & 0.73 \\
\hline 18 & Cibugel & 2.18 & - & 0.36 & 1.03 & 0.95 & 0.62 & 1.00 & 0.71 & 1.00 & 0.88 \\
\hline 19 & Tanjungmedar & 1.85 & - & 0.17 & 1.09 & 0.91 & 0.92 & 0.75 & 1.03 & 1.52 & 0.93 \\
\hline 20 & Cisitu & 1.61 & - & 0.28 & 1.65 & 0.77 & 0.90 & 0.72 & 1.25 & 1.72 & 0.89 \\
\hline 21 & Pamulihan & 1.22 & 0.06 & 0.94 & 1.21 & 1.11 & 1.00 & 0.62 & 0.47 & 0.89 & 0.85 \\
\hline 22 & Ganeas & 1.23 & - & 0.48 & 1.70 & 1.15 & 0.79 & 1.88 & 1.57 & 1.73 & 0.92 \\
\hline 23 & Jatinunggal & 1.78 & - & 0.23 & 1.38 & 1.66 & 0.81 & 0.52 & 1.04 & 1.67 & 0.89 \\
\hline 24 & Sukasari & 1.27 & - & 0.59 & 1.53 & 1.34 & 0.85 & 1.37 & 1.64 & 1.19 & 0.91 \\
\hline 25 & Cisarua & 1.03 & - & 0.52 & 1.63 & 1.16 & 1.14 & 1.09 & 1.45 & 1.44 & 0.92 \\
\hline \multirow[t]{2}{*}{26} & Surian & 2.23 & 0.66 & 0.17 & 2.08 & 1.83 & 0.33 & 1.17 & 0.76 & 1.74 & 0.96 \\
\hline & $\alpha$ & 0.29 & 0.75 & 0.35 & 0.10 & 0.11 & 0.17 & 0.22 & 0.11 & 0.11 & \\
\hline
\end{tabular}

\section{Keterangan:}

$1=$ sektor pertanian

$2=$ sektor Pertambangan/penggalian

$3=$ sektor industri pengolahan

$4=$ sektor listrik, gas dan air bersih

$6=$ sektor perdagangan, hotel dan restoran

$7=$ sektor pengangkutan dan komunikasi

$8=$ sektor keuangan, persewaan dan jasa

Perusahaan

$9=$ sektor jasa-jasa

$\alpha=$ koefisien lokalisasi

$\beta=$ koefisien spesialisasi

Penjabaran hasil analisis Location Quotient dikelompokkan berdasarkan karakteristik sektor basis disajikan pada Tabel 7 berikut :

Tabel 7.Karakteristik Sektor Basis di Kabupaten Sumedang Tahun 2008 dan 2012

\begin{tabular}{|c|c|c|c|}
\hline \multirow{2}{*}{ No } & \multirow{2}{*}{ Kecamatan } & \multicolumn{2}{|c|}{ Sektor Basis } \\
\hline & & 2008 & 2012 \\
\hline 1 & Jatinangor & Industri pengolahan; Jasa-jasa & Industri pengolahan; Jasa-jasa \\
\hline 2 & Cimanggung & Industri pengolahan & Industri pengolahan; Listrik, gas dan air bersih \\
\hline 3 & Tanjungsari & $\begin{array}{l}\text { Listrik, gas dan air bersih; Bangunan/konstruksi; } \\
\text { Perdagangan, hotel dan restoran; Pengangkutan dan } \\
\text { komunikasi; Keuangan, persewaan dan jasa } \\
\text { perusahaan; Jasa-jasa }\end{array}$ & $\begin{array}{l}\text { Listrik, gas dan air bersih; Bangunan/ konstruksi; } \\
\text { Perdagangan, hotel dan restoran; Pengangkutan } \\
\text { dan komunikasi; Keuangan, persewaan dan jasa } \\
\text { perusahaan; Jasa-jasa }\end{array}$ \\
\hline 4 & Rancakalong & $\begin{array}{l}\text { Pertanian; Listrik, gas dan air bersih; } \\
\text { Bangunan/konstruksi;Keuangan, perse-waan dan } \\
\text { jasa perusahaan; Jasa-jasa }\end{array}$ & $\begin{array}{l}\text { Pertanian; Listrik, gas dan air bersih; } \\
\text { Bangunan/konstruksi; Keuangan, pers-ewaan dan } \\
\text { jasa perusahaan; Jasa-jasa }\end{array}$ \\
\hline 5 & $\begin{array}{l}\text { Sumedang } \\
\text { Selatan }\end{array}$ & $\begin{array}{l}\text { Bangunan/konstruksi; Perdagangan, hotel dan } \\
\text { restoran; Pengangkutan dan komunikasi; Keuangan, } \\
\text { persewaan dan jasa perusahaan; Jasa-jasa }\end{array}$ & $\begin{array}{l}\text { Bangunan/konstruksi; Perdagangan, hotel dan } \\
\text { restoran; Pengangkutan dan komunikasi; } \\
\text { Keuangan, persewaan dan jasa perusahaan; Jasa- } \\
\text { jasa }\end{array}$ \\
\hline 6 & $\begin{array}{l}\text { Sumedang } \\
\text { Utara }\end{array}$ & $\begin{array}{l}\text { Perdagangan, hotel \&Restoran; Peng-angkutan dan } \\
\text { komunikasi; Keuangan, persewaan dan jasa } \\
\text { perusahaan }\end{array}$ & $\begin{array}{l}\text { Perdagangan, hotel dan restoran; Peng-angkutan } \\
\text { dan komunikasi; Keuangan, persewaan dan jasa } \\
\text { perusahaan }\end{array}$ \\
\hline 7 & Situraja & $\begin{array}{l}\text { Pertanian; Listrik, gas dan air bersih; Keuangan, } \\
\text { persewaan dan jasa perusahaan; Jasa-jasa }\end{array}$ & $\begin{array}{l}\text { Pertanian; Keuangan, persewaan dan jasa } \\
\text { perusahaan; Jasa-jasa }\end{array}$ \\
\hline 8 & Darmaraja & $\begin{array}{l}\text { Pertanian; Pengangkutan dan komu-nikasi; } \\
\text { Keuangan, persewaan dan jasa perusahaan; Jasa- } \\
\text { jasa }\end{array}$ & $\begin{array}{l}\text { Pertanian; Bangunan/konstruksi; Peng-angkutan } \\
\text { \&komunikasi; Keuangan, persewaan \&jasa } \\
\text { perusahaan; Jasa-jasa }\end{array}$ \\
\hline 9 & Wado & $\begin{array}{l}\text { Pertanian; Listrik, gas dan air } \\
\begin{array}{l}\text { Bangunan/konstruksi; } \\
\text { komunikasi }\end{array}\end{array}$ & $\begin{array}{l}\text { Pertanian; Listrik, gas dan air bersih; } \\
\text { Bangunan/konstruksi; } \\
\text { komunikasi }\end{array}$ \\
\hline 10 & Jatigede & $\begin{array}{lllr}\text { Pertanian; Listrik, gas dan air } & \text { bersih; } \\
\text { Bangunan/konstruksi; } & \text { Pengangkutan } & \text { dan } \\
\text { komunikasi; Keuangan, persewaan dan } & \text { jasa } \\
\text { perusahaan; Jasa-jasa } & & & \end{array}$ & $\begin{array}{l}\text { Pertanian; Listrik, gas dan air bersih; } \\
\text { Bangunan/konstruksi; } \\
\begin{array}{l}\text { komunikas; } \text { Pengangkutan } \\
\text { perusahaan; Jasa-jasa }\end{array}\end{array}$ \\
\hline 11 & Tomo & $\begin{array}{l}\text { Pertanian; Pertambangan dan peng-galian; } \\
\text { Keuangan, persewaan dan jasa perusahaan }\end{array}$ & $\begin{array}{l}\text { Pertanian; Pertambangan dan peng-galian; } \\
\text { Keuangan, persewaan dan jasa perusahaan }\end{array}$ \\
\hline
\end{tabular}




\begin{tabular}{|c|c|c|c|}
\hline 12 & Ujungjaya & Pertanian; Pertambangan/penggalian & Pertanian; Pertambangan/penggalian \\
\hline 13 & Conggeang & $\begin{array}{l}\text { Pertanian; Pertambangan/ penggalian; Listrik, gas } \\
\text { dan air bersih; Pengangkutan dan komunikasi }\end{array}$ & $\begin{array}{l}\text { Pertanian; Pertambangan/penggalian; } \\
\text { Pengangkutan dan komunikasi }\end{array}$ \\
\hline 14 & Paseh & $\begin{array}{l}\text { Pertanian; Pertambangan/ penggalian; Listrik, gas } \\
\text { dan air bersih; Bangunan/konstruksi; Perdagangan, } \\
\text { hotel dan restoran; Pengangkutan dan komunikasi }\end{array}$ & $\begin{array}{l}\text { Pertanian; } \\
\text { Bangunan/konstruksi; Perdambangan/penggalian; } \\
\text { restoran; Pengangkutan dan komunikasi }\end{array}$ \\
\hline 15 & Cimalaka & $\begin{array}{l}\text { Pertambangan/penggalian; Listrik, gas dan air } \\
\text { bersih; Bangunan/ konstruksi; Perdagangan, hotel } \\
\text { dan restoran; Pengangkutan dan komunikasi; Jasa- } \\
\text { jasa }\end{array}$ & $\begin{array}{l}\text { Pertambangan/penggalian; Listrik, gas dan air } \\
\text { bersih; Bangunan/ konstruksi; Perdagangan, hotel } \\
\text { dan restoran; Pengangkutan dan komunikasi; } \\
\text { Jasa-jasa }\end{array}$ \\
\hline 16 & Tanjungkerta & $\begin{array}{llr}\text { Pertanian; Listrik, gas dan air } & \text { bersih; } \\
\text { Bangunan/konstruksi; } & \text { Pengangkutan } & \text { dan } \\
\text { komunikasi; Keuangan, } & \text { persewaan dan } & \text { jasa } \\
\text { perusahaan; Jasa-jasa }\end{array}$ & 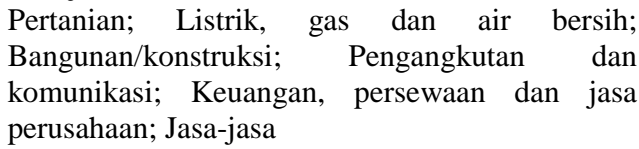 \\
\hline 17 & Buahdua & Pertanian; Pertambangan/penggalian & Pertanian; Pertambangan/penggalian \\
\hline 18 & Cibugel & Pertanian; Listrik, gas dan air bersih & $\begin{array}{l}\text { Pertanian; Listrik, gas dan air bersih; } \\
\text { Pengangkutan \& komunikasi; Jasa-jasa }\end{array}$ \\
\hline 19 & $\begin{array}{l}\text { Tanjung- } \\
\text { medar }\end{array}$ & $\begin{array}{l}\text { Pertanian; Listrik, gas dan air bersih; Keuangan, } \\
\text { persewaan dan jasa perusahaan; Jasa-jasa }\end{array}$ & $\begin{array}{l}\text { Pertanian; Listrik, gas dan air bersih; Keuangan, } \\
\text { persewaan dan jasa perusahaan; Jasa-jasa }\end{array}$ \\
\hline 20 & Cisitu & $\begin{array}{l}\text { Pertanian; Listrik, gas dan air bersih; Keuangan, } \\
\text { persewaan dan jasa perusahaan; Jasa-jasa }\end{array}$ & $\begin{array}{l}\text { Pertanian; Listrik, gas dan air bersih; Keuangan, } \\
\text { persewaan dan jasa perusahaan; Jasa-jasa }\end{array}$ \\
\hline 21 & Pamulihan & $\begin{array}{l}\text { Pertanian; Listrik, gas dan air bersih; } \\
\text { Bangunan/konstruksi; } \\
\text { restoran }\end{array}$ & $\begin{array}{l}\text { Pertanian; Listrik, gas dan air bersih; } \\
\text { Bangunan/konstruksi; Perdagangan, hotel dan } \\
\text { restoran }\end{array}$ \\
\hline 22 & Ganeas & $\begin{array}{l}\text { Pertanian; Listrik, gas dan air bersih; } \\
\begin{array}{l}\text { Bangunan/konstruksi; } \\
\text { komunikasi; Keuangan, persewangkan dan }\end{array} \\
\begin{array}{l}\text { perusahaan; Jasa-jasa } \\
\text { pasa }\end{array}\end{array}$ & $\begin{array}{l}\text { Pertanian; Listrik, gas dan air bersih; } \\
\text { Bangunan/konstruksi; } \\
\text { komunikasi; Keuangan, persewaan dan } \\
\begin{array}{l}\text { perusahaan; Jasa-jasa } \\
\text { pasa }\end{array}\end{array}$ \\
\hline 23 & Jatinunggal & $\begin{array}{l}\text { Pertanian; Listrik, gas dan air bersih; } \\
\text { Bangunan/konstruksi; Keuangan, perse-waan dan } \\
\text { jasa perusahaan; Jasa-jasa }\end{array}$ & $\begin{array}{l}\text { Pertanian; Listrik, gas dan air bersih; } \\
\text { Bangunan/konstruksi; Keuangan, perse-waan dan } \\
\text { jasa perusahaan; Jasa-jasa }\end{array}$ \\
\hline 24 & Sukasari & $\begin{array}{l}\text { Pertanian; Listrik, gas dan air bersih; } \\
\begin{array}{l}\text { Bangunan/konstruksi; } \\
\text { komunikasi; Keuangan, }\end{array} \text { pergangkutan } \\
\begin{array}{l}\text { perusahaan; Jasa-jasa } \\
\text { dan }\end{array}\end{array}$ & $\begin{array}{l}\text { Pertanian; Listrik, gas dan air bersih; } \\
\text { Bangunan/konstruksi; } \\
\begin{array}{l}\text { komunikasi; Kengangkutan } \\
\text { perusahaan; Jasa-jasa }\end{array}\end{array}$ \\
\hline 25 & Cisarua & $\begin{array}{l}\text { Pertanian; Listrik, gas dan air bersih; } \\
\text { Bangunan/konstruksi; Perdagangan, hotel dan } \\
\text { restoran; Pengangkutan dan komunikasi; Keuangan, } \\
\text { persewaan dan jasa perusahaan; Jasa-jasa }\end{array}$ & $\begin{array}{l}\text { Pertanian; Listrik, gas dan air bersih; } \\
\text { Bangunan/konstruksi; Perdagangan, hotel dan } \\
\text { restoran; Pengangkutan dan komunikasi; } \\
\text { Keuangan, persewaan dan jasa perusahaan; Jasa- } \\
\text { jasa }\end{array}$ \\
\hline 26 & Surian & $\begin{array}{lrrr}\text { Pertanian; Listrik, } & \text { gas dan air } & \text { bersih; } \\
\text { Bangunan/konstruksi; } & \text { Pengangkutan } & \text { dan } \\
\text { komunikasi; Jasa-jasa } & & & \end{array}$ & $\begin{array}{l}\text { Pertanian; Listrik, gas dan air bersih; } \\
\text { Bangunan/konstruksi; } \\
\text { komunikasi; Jasa-jasa }\end{array}$ \\
\hline
\end{tabular}

\section{Efek Pengganda Basis (base multifleir effect)}

Melalui efek pengganda (multiplier), maka pertumbuhan ekonomi suatu wilayah dapat diketahui. Efek pengganda sebagai siklus dari pembelanjaan kembali pendapatan yang diperoleh melalui penjualan barang dan jasa yang dihasilkan oleh wilayah yang bersangkutan. Pengganda pendapatan basis dihitung dengan membandingkan total pendapatan wilayah dengan pendapatan dari sektor basis. Besarnya efek pengganda ini akan mendorong pertumbuhan ekonomi wilayah yang ditunjukkan dengan koefisien pengganda yang dihasilkan oleh kegiatan ekonomi di wilayah yang bersangkutan. 
Tabel 8. Efek Pengganda Basis (Base Multiplier Effect) Kabupaten Sumedang

\begin{tabular}{clcc}
\hline No & & 2008 & 2012 \\
\hline 1 & Jatinangor & 1.58 & 1.62 \\
2 & Cimanggung & 1.33 & 1.34 \\
3 & Tanjungsari & 1.86 & 1.76 \\
4 & Rancakalong & 1.65 & 1.72 \\
5 & Sumedang Selatan & 1.40 & 1.34 \\
6 & Sumedang Utara & 1.47 & 1.43 \\
7 & Situraja & 1.77 & 1.95 \\
8 & Darmaraja & 1.73 & 1.80 \\
9 & Wado & 1.94 & 2.00 \\
10 & Jatigede & 1.40 & 1.43 \\
11 & Tomo & 2.55 & 2.75 \\
12 & Ujungjaya & 1.88 & 1.98 \\
13 & Conggeang & 2.09 & 2.34 \\
14 & Paseh & 1.61 & 1.60 \\
15 & Cimalaka & 2.02 & 1.92 \\
16 & Tanjungkerta & 1.57 & 1.63 \\
17 & Buahdua & 1.69 & 1.77 \\
18 & Cibugel & 1.73 & 1.80 \\
19 & Tanjungmedar & 1.52 & 1.57 \\
20 & Cisitu & 1.56 & 1.61 \\
21 & Pamulihan & 1.55 & 1.55 \\
22 & Ganeas & 1.51 & 1.54 \\
23 & Jatinunggal & 1.51 & 1.45 \\
24 & Sukasari & 1.61 & 1.65 \\
25 & Cisarua & 1.16 & 1.15 \\
26 & Surian & 1.19 & 1.21 \\
& Rata-rata & 1.65 & 1.69 \\
\hline & & &
\end{tabular}

Pada Tabel 8, terlihat koefisien pengganda pendapatan sektor basis pada tahun 2008 menunjukkan nilai rata-rata 1,65 dan tahun 2012 adalah 1,69. Dari tahun-ketahun terlihat kecenderungannnya semakin membesar. Hal ini mengandung pengertian

\section{Ketimpangan Wilayah di Kabupaten Sumedang}

Ketimpangan pembangunan ekonomi antar wilayah merupakan fenomena umum yang terjadi dalam proses pembangunan ekonomi suatu daerah. Ketimpangan ini pada awalnya disebabkan oleh perbedaa kandungan sumerdaya alam dan kondisi demografi yang bahwa sektor-sektor basis ini mampu memberikan dampak terhadap pembentukan PDRB sebesar 1,65 s.d 1,69 kali dari total output yang dihasilkan oleh sektor basis di Kabupaten Sumedang. terdapat pada masing-masing wilayah. Ketimpangan antar wilayah ini membawa implikasi pada tingkat kesejahteraaan masyarakat pada wilayah yang bersangkutan (Syafrizal, 2014). 
Tabel 9. Analisis Ketimpangan Wilayah di Kabupaten Sumedang

\begin{tabular}{ccc}
\hline No & Tahun & Nilai Ketimpangan \\
\hline 1 & 2008 & 0.44 \\
2 & 2009 & 0.45 \\
3 & 2010 & 0.45 \\
4 & 2011 & 0.45 \\
5 & 2012 & 0.43 \\
\hline
\end{tabular}

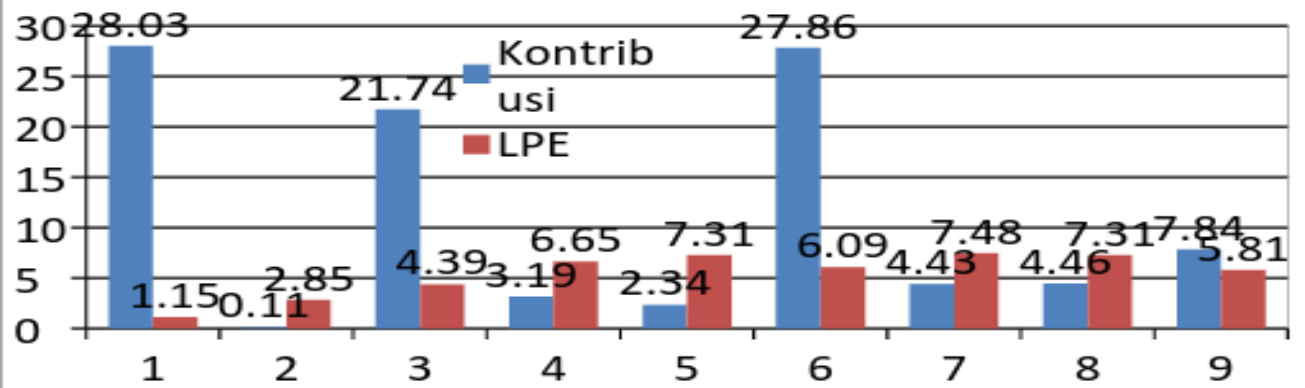

Sumber : Bapeda Kabupaten Sumedang Tahun 2015

Gambar 1. Kontribusi dan LPE Sektoral di Kabupaten Sumedang

Berdasarkan data pada Tabel 9, secara umum tingkat ketimpangan Kabupaten Sumedang termasuk ketimpangan moderat karena memiliki nilai ketimpangan antara $0,3 \leq 0,5$. Dalam kurun waktu lima tahun indeks ketimpangan wilayah relative stabil berkisar 0,44 .

Sektor pertanian memiliki kontribusi terbesar terhadap PDRB Kabupatern Sumedang, Namun laju pertumbuhan ekonominya terkecil. Hal ini menunjukkn nilai tambah yang diperoleh dari sektor pertanian relative kecil, oleh karena itu sektor pertanian perlu lebih didorong dengan tetap memperhatikan sektor lainnya $\mathrm{Hal}$ ini sejalan dengan. RTRW Kabupaten Sumedang Tahun 2011 - 2031 yang memiliki visi "Mewujudkan Sumedang sebagai kabupaten agribisnis yang didukung oleh kepariwisataan dan perindustrian secara efektif, berdaya saing, dan berkelanjutan. Oleh karena itu sektor usaha lainnya sebagai pendukung perlu terus ditingkatkan dan dikembangkan.

Pertumbuhan ekonomi yang baik adalah pertumbuhan ekonomi yang dibarengi dengan pemerataan pendapatan di masyarakat. Bila dilihat pada kondisi perekonomian di masingmasing kecamatan, maka terdapat beberapa kecamatan yang berkembang baik, namun ada 
beberapa kecamatan yang tertinggal dalam perkembangan perekonomiannya.

Berdasarkan hasil analisis Gini ratio yang dilakukan oleh Bappeda Kabupaten Sumedang diketahui bahwa hanya Kecamatan Cimanggung danTanjungsari memeiliki pertumbuhan ekonomi cukup baik dan diikuti dengan pemerataan pendapatan. Karakteristik perekonomian kecamatan Tanjungsari dan Cimanggung didominasi oleh sektor industri pengolahan, perdagangan, hotel dan restoran. Kabupaten Sumedang memiliki LPE pada tahun 2012 sebesar 4,82\% dan indek gini sebesar : 0,306 poin.

Kuadran I adalah kecamatan dengan LPE dan pendapatan per kapita > Kabupaten
Sumedang, Kuadran II adalah wilayah yang memiliki LPE < Kabupaten , namun pendapatan perkapita > kabupaten, Kuadran III adalah Kecamatan yang memiliki LPE dan pendapatan perkapiata $<$ kabupaten dan kuadranIV adalah kecamatan yang memiliki LPE > Sumedang, namun pendapatan per kapita $<$ Sumedang. Kecamatan yang bersifat perkotaan (kuadran I) ternyata lebih didominasi oleh sektor usaha perdagangan dan jasa memiliki perekonomian yang lebih baik dibandingkan dengan kecamatan yang bersifat perdesaan (terutama kuadran III).

Tabel 10. Indeks Gini dan LPE Per Kecamatan di Kabupaten Sumedang 2012

\begin{tabular}{llcclllc}
\hline No & Kecamatan & Indeks Gini & LPE & No & Kecamatan & Indeks Gini & LPE \\
\hline 1 & Sumedang Selatan & 0,403 & 5,90 & 14 & Situraja & 0,328 & 3,68 \\
2 & Sumedang Utara & 0,344 & 6,41 & 15 & Cisitu & 0,229 & 3,82 \\
3 & Ganeas & 0,251 & 4,05 & 16 & Darmaraja & 0,332 & 3,72 \\
4 & Cimalaka & 0,303 & 4,84 & 17 & Cibugel & 0,344 & 2,75 \\
5 & Cisarua & 0,559 & 4,23 & 18 & Jatingunggal & 0,305 & 3,88 \\
6 & Tanjungkerta & 0,385 & 3,69 & 19 & Wado & 0,322 & 4,01 \\
7 & Tanjungmedar & 0,263 & 3,56 & 20 & Conggeang & 0,416 & 3,93 \\
8 & Tanjungsari & 0,292 & 5,46 & 21 & Surian & 0,213 & 2,82 \\
9 & Sukasari & 0,215 & 3,91 & 22 & Buah Dua & 0,285 & 3,30 \\
10 & Pamulihan & 0,168 & 4,61 & 23 & Paseh & 0,230 & 4,64 \\
11 & Rancakalong & 0,269 & 4,13 & 24 & Ujungjaya & 0,327 & 3,20 \\
12 & Jatinangor & 0,412 & 5,97 & 25 & Tomo & 0,330 & 3,86 \\
13 & Cimanggung & 0,228 & 5,20 & 26 & Jatigede & 0,214 & 3,08 \\
\hline
\end{tabular}

Sumber : Bappeda Kabupaten Sumedang, 2015 


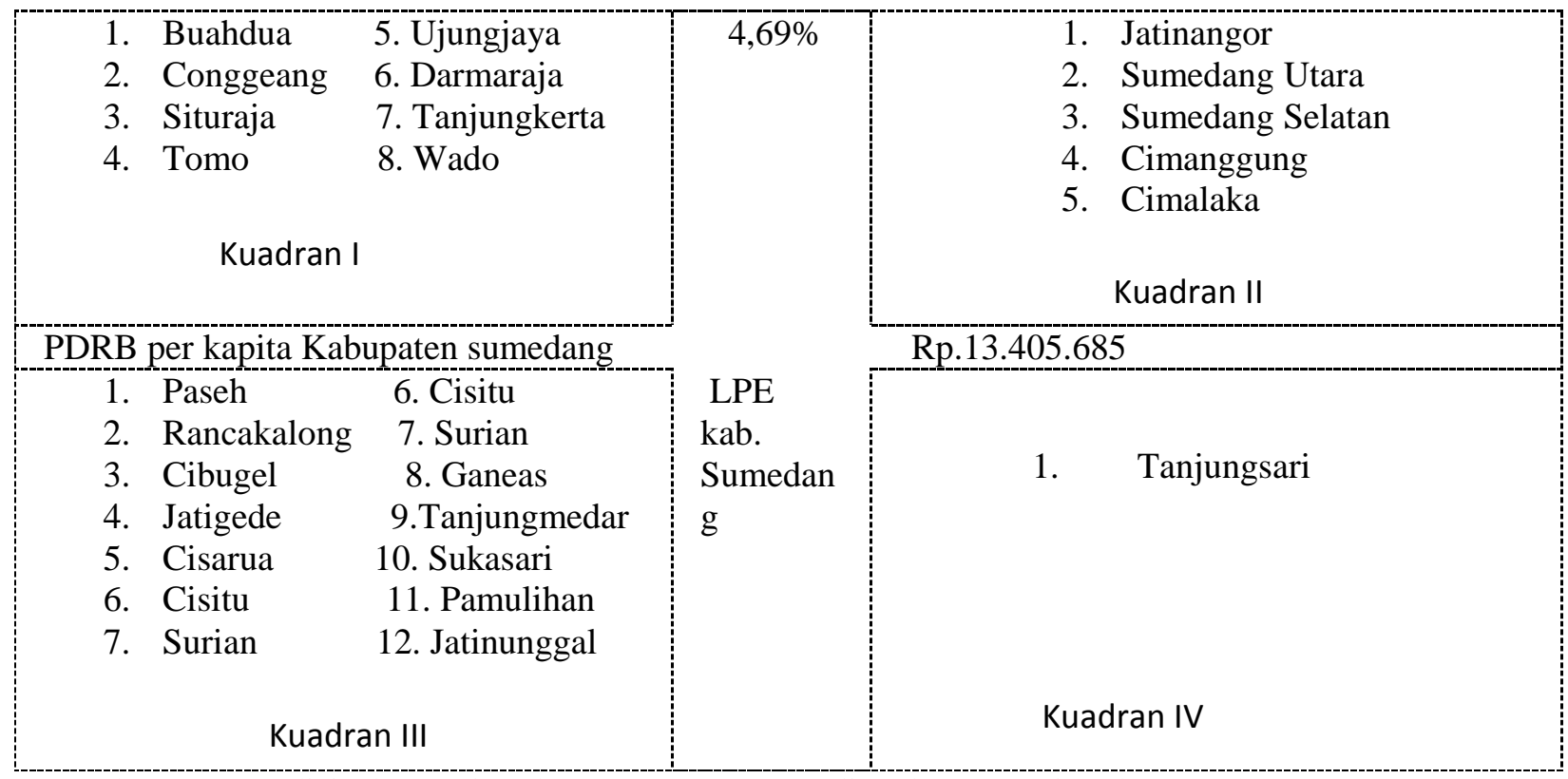

Gambar 2. Kondisi Ekonomi makro per Kecamatan di Kabupaten Simedang Tahun 2012

Sumber : Bappeda Sumedang, 2015

\section{KESIMPULAN DAN SARAN}

1. Wilayah dengan tingkat pertumbuhan dan daya saing lebih tinggi dari wilayah lainnya adalah Kecamatan Jatinangor, Cimalaka, Sumedang Utara, Cimanggung, Paseh, Sumedang selatan, Tanjungsari dan Pamulihan. Empat sektor memiliki pertumbuhan yang lebih lambat dibandingkan pertumbuhan rata-rata seluruh sektor yaitu pertanian, pertambangan / penggalian, industri pengolahan dan Jasa.

2. Secara keseluruhan

(Total

Change) pertumbuhan dan pergeseran tertinggi untuk sektor pertanian terjadi di Kecamatan Buahdua, sektor pertambangan/penggalian di Kecamatan Paseh, sektor industri pengolahan di Kecamatan Sumedang utara, sektor listrik, gas, air bersih dan bangunan di Kecamatan Jatinangor, sektor perdagangan, hotel, dan restoran di Kecamatan Sumedang Utara, sektor pengangkutan, komunikasi, keuangan, persewaan, dan jasa perusahaan di Kecamatan Sumedang Selatan dan sektor jasa di Kecamatan Jatinangor. Perubahan total dengan nilai positif tertingi terdapat pada lima kecamatan yaitu Kecamatan Jatinangor, SumedangUtara, Cimanggu ng, Sumedang Selatan dan Tanjungsari.

3. Terjadi Transformasi Struktur perekonomian Kabupaten Sumedang dari sektor primer ke sektor sekunder dan tersier. Sektor potensial yang menjadi 
pengerak pertumbuhan (leading sector), memberikan kontribusi yang besar karena memiliki keunggulan kompetitifdan komparatif serta mampu berspesialisasi di wilayah perdesaan (kecamatan pada kuadran III) adalah pertanian, sedangkan daerah perkotaan ( kuadaran I) adalah Industri Pengolahan, perdagangan, hotel dan restoran serta jasa.

4. Ketimpangan distribusi pendapatan Kabupaten sumedang relative rendah berkisar $0,2 \quad-0,5$ dan ketimpangan wilayah di Kabupaten Sumedang termasuk moderat dengan nilai indeks ketimpangan relative stabil sebesar 0,44.

Sektor pertanian dibeberapa kecamatan masih memberikan kontribusi yang besar dalam perekonomian wilayah namun memiliki laju pertumbuhan ekonomi yang rendah,

\section{DAFTAR PUSTAKA}

Adisasmita, Rahardjo. 2008. Pengembangan Wilayah : konsep dan Teori. Yogyakarta: Graha Ilmu.

Bappeda kabupaten sumedang, 2015. Sinergitas Rencana Kegiatan Iptek bagi wilayah (Ibw) antara Unpad dengan Pemerintah Kabupaten Sumedang, Sumedang

BPS dan Bappeda Kabupaten Sumedang, 2013.

Indikator Ekonomi Makro PDR $B$ Menurut Lapangan Usaha kabupaten Sumedang 20082012, Katalog BPS 9218.3211

BPS, 2013. Produk Domestik Regional Bruto Kabupaten Sumedang Menurut Kecamatantahun2008- artinya nilai tambahnya relatif kecil. Oleh karena itu disarankan Pemda Sumedang dapat merumuskan kebijakan pengembangan agroindustri yang sinergis dengan sektor potensial lainnya agar menghasilkan multiflier effect terhadap peningkatan pendapatan masyarakat dan percepatan pembangunan ekonomi yang efektif dan efisien.

Guna meningkatkan pertumbuhan dan mengurangi ketimpangan wilayah, khususnya di wilayah kecamatan yang berbasis sektor pertanian dan kurang berkembang, perlu meningkatkan fasilitas pelayanan berupa sarana dan prasarana, infrastruktur serta yang dapat mendukung aktifitas sosial dan ekonomi melalui pembangunan dengan pendekatan agroindustri dan agribisnis yang berkelanjutan.

2012, Bappeda Kabupaten Sumedang

---------, 2014. Kabupaten Sumedang dalam Angka Tahun 2013. BPS Kabupaten sumedang, katalog bps : 110201.0211

Deddy M. Dan Sonny I, 2013. Analisis Pergeseran struktur Ekonomi dan Identifikasi sektor potensial wilayah pengembangan, volume 2 nomor 1, April 2013, Jurnal Social Economic of Agriculture. Jurusan Sosial Ekonomi Faperta Universitas Tanjungpura,Kalimanatan Barat

Budiharsono, Sugeng 2001. Teknik Analisis Pembangunan Wilayah Pesisir 
dan Lautan, Jakarta:

Pradnya Paramita

Suparno, 2008. Analisis Pergeseran Struktur ekonomi dan Penentuan Sektor Unggulan Kawasan

Sulawesi.(Skripsi) IPB,

Bogor.Tidak dipublikasikan.

Syafrizal. 2008. Ekonomi Regional, teori dan aplikasi. Padang: Baduose Media.

2014.. Ekonomin Wilayah dan

Perkotaan, PT Rajagrafindo Persada, Jakarta.
Tarigan, Robinson. 2007. Ekonomi Regional,Tteori dan Aplikasi. Jakarta: PT Bumi Aksara. 2005. Perencanaan Pembangunan Wilayah, Jakarta: PT Bumi Aksara

Todaro, Michael,dan Stephen C Smith, 2006. PembangunanEkonomi Edisi Kesembilan Jilid I, Jakarta: Erlangga.

Penulis adalah staf pengajar di fakultas pertanian Unpad 